University for Business and Technology in Kosovo

UBT Knowledge Center

Oct 27th, 1:30 PM - 3:00 PM

\title{
The determinants of bank interest rate margins: A panel approach for some Balkan countries
}

\author{
Fidane Spahija Gjikolli \\ University for Business and Technology, fidane.spahija@ubt-uni.net
}

Follow this and additional works at: https://knowledgecenter.ubt-uni.net/conference

Part of the Business Commons

\section{Recommended Citation}

Gjikolli, Fidane Spahija, "The determinants of bank interest rate margins: A panel approach for some Balkan countries" (2018). UBT International Conference. 312.

https://knowledgecenter.ubt-uni.net/conference/2018/all-events/312

This Event is brought to you for free and open access by the Publication and Journals at UBT Knowledge Center. It has been accepted for inclusion in UBT International Conference by an authorized administrator of UBT Knowledge Center. For more information, please contact knowledge.center@ubt-uni.net. 


\title{
The determinants of bank interest rate margins: A panel analysis for some Balkan countries
}

\author{
Fidane Spahija Gjikolli ${ }^{1}$ \\ ${ }^{1}$ University of Business and Technology, Kosovo \\ fidane.spahija@ubt-uni.net
}

\begin{abstract}
Studying interest rates has always been in focus of researches. Loans are the main source of funds for businesses and individuals, especially in the Balkan countries. The main problem is that high interest rate margins can indicate many factors, such as: The informal economy, problems with the cadaster system, an ineffective job of courts, the inability of Central Banks to inject liquidity, weaknesses in the quality of financial reporting of businesses, non-performing loans. It looks like all these problems are in favor of banks, by maximizing their profit. It is well known that the intermediary role of bank is to provide the best prosperity for society, preferably at the lowest possible costs. The high level of interest rate spread is an indicator of inefficiency, excessive risk taking and lack of competition. This study aims to measure the effects of the banking, market and macroeconomic structure on the net interest rate spread of the Balkan countries, such as Albania, Kosovo, Macedonia, Bosnia and Herzegovina, and Serbia, for seven years. According with this, the evaluation is made from two tips of methods: statistical and regression analysis. In the end, I can conclude that the net interest margin is influenced by maintaining high levels of capital, non-performing loans, operating expenses and bank capital ownership. Other factors that affect it are bank size, liquidity risk and portfolios performance. Macroeconomic components such as: Market Structure and Gross Domestic Product are assessed without impact. The study of factors that may cause changes in interest rate margins is an interesting and widely dealt with by foreign literature. Such an approach may be useful for specific measures of economic policy, taking into account the prospect of EU integration and other researcher that want to expand this study.
\end{abstract}

Key words: Interest rate margins, capital, risk, ownership and competition. 


\section{Introduction}

Building a healthy banking sector is one of the fundamental aspects of the transition Balkan countries to a market economy. The banking system is the most important element of the financial system of these countries, whose assets is about 90 percent of the total assets of financial system. Interest rates continue to remain part of the global debate. Banks function as the main players in channeling funds from lenders to borrowers, so it is important that their intermediary role provides a higher welfare for society, preferably at lower cost. In this context, the main point of research is to identify the factors that affecting the net interest margin (NIM) for the banking system of some Balkan countries. The objective of this study is to measure the effects of banking, market and macroeconomic structures on the net interest margin of the Balkan countries, such as Albania, Kosovo, Macedonia, Bosnia and Herzegovina and Serbia, for the period of 2011-2017. In other words, the objective of this study is to determine which of the factors has the highest effect on the interest rate margins in the Balkan countries. This study may be useful for specific measures of economic policy, taking into account the prospect of EU integration, while the area of net interest margins is always on the lookout.

\subsection{The main of literature}

The theoretical framework on interest rates has been more than enough, from foreign and local literature. The theoretical part includes a detailed analysis of factors that affecting the net interest rate spread by theoretical, accounting and empirical results. A highly theoretical framework on NIM determinants was presented by Ho and Saunders (1981). This theoretical framework has been expanded by many other studies, such as Maudos and Fernández de Guevara (2004); Clayes and Vander Vennet (2007). According to the theoretical framework, the net interest rate spread is influenced by banking, market and macroeconomic characteristics. Within the banking characteristics are included: Portfolio performance, which is measured by the ratio of loans to total assets. Clayes (2007) Risk Sustainability, which represents the ratio of capital to total assets. Demirgüç-Kunt and Huizinga (1999), Demirgüç-Kunt et al. (2004), Sologoub (2006) . Liquidity risk is determined by liquid assets to total assets. Angbazo (1997); Demirgüç-Kunt et al., (2004); Martinez Peria and Mody, (2004). Credit risk representing the ratio of non-performing loans to total gross loans. Drakos (2002); Maudos and Fernández de Guevara, (2004). Operating expenses calculated in relation to total assets. Demirgüç-Kunt and Huizinga (1999); Abreu and Mendes (2003); Demirgüç-Kunt and others (2004); Maudos and Fernández de Guevara (2004); Martinez Peria and Mody (2004); Claeys and Vander Vennet, (2007). Size of banks calculated by asset size. Naceur (2003); Martinez Peria and Mody (2004); Gual, (1999) The ownership of banks represents the last variable within the banking characteristics; Demirgüç-Kunt and Huizinga (1999); Martinez Peria and Mody (2004); Demirgüç-Kunt et al. (2004); Sapienza (2002). In addition to analyzing 
the theoretical framework of banking characteristics, we also have market and macroeconomic characteristics. Within the framework of market characteristics we have the market structure variable expressed through HHI, as appreciated by many different authors. Berger, (1995b); Carbo and Rodriguez (2007); Demsetz (1973) Claeys and Vander Vennet (2007); Maudos and Fernández de Guevara (2004) Martinez Peria and Mody (2004). In terms of macroeconomic characterizations we have GDP. Demirgüç-Kunt and Huizinga (1999); Demirgüç-Kunt et al. (2004); Brock and Suarez (2000); Claeys and Vander Vennet (2007); Vein, Carbo and Rodriguez, (2007); Drakos (2002).

\subsection{Data, methodology and sources of work}

The paper has an evaluation character. Investigation of this research was done for 116 commercial banks. The data refer to the period 2011-2017, unbalanced with a total of 812 observations. The data was collected and processed in Excel by being transmitted as a panel in the STATA version 11.0 program, evaluating through the Houseman test with the random effect method. Testing hypothesis is done with tests as: $\mathrm{R}^{2}$ and Wald $\mathrm{chi}^{2}$. While empirical results are presented with the static and dynamic model.

The methods used are descriptive, comparative and regression analysis. All variables used in the paper contain quantitative character. The main sources of study are: Bank scope, IMF, World Bank, ECB, Central Banks of study countries.

By analyzing data for the Balkan countries through the dealer model (Ho and Saunders, 1986), we build the research questions and hypotheses that were tested, and helped to find the result and conclusion.

\subsection{Research question \& working hypotheses}

Formulating the research questions and hypothesis, we started from two facts:

First, for years, in countries such as Kosovo, the level of capital adequacy (i.e. the ratio of regulatory capital to risk-weighted assets) is much higher than the minimum level required by the Central Bank of Kosovo. As in 2017, the actual level of capital adequacy was $19 \%$ on average, higher as required level of $12 \%$ minimum;

Second, the perceptions of business and individuals are well-known that bank loan interest rates are extremely high, while those of bank deposits are quite low.

The central question of the paper is:

- Why businesses and individuals in countries like Kosovo perceive as very high the interest rates on bank loans, at the same time when interest rates of deposit are perceived as very low?

Second questions of paper are:

- What are the effects on the net interest rate spreads of such risk factors such as the ratio of regulatory capital to risk-weighted assets, operating expenses, total loan / total ratio, non-performing / gross credit ratio, and the liquid assets ratio / total tools? 
- After looking for other factors, who has a lot to do with raising the net interest margin: foreign-owned banks or local-owned banks?

- Is it no higher average level of competition in the banking system one of the factors of raising the interest rate margin?

Regarding to this, we build a total four hypothesis; include a basic hypothesis and three other hypothesis which are presented below.

Basic hypothesis: In countries like Kosovo, a higher level of the capital adequacy ratio of the relatively low level required by the central bank ensures the banks' sustainability in case of large and unexpected losses, on the one hand, but it is also the main factor in increasing the net interest margin, on the other.

Hypothesis 2: The performance effects of the portfolio, operating expenses, credit risk and liquidity are attached to the effect of capital on the growth of net interest rate margins.

Hypothesis 3: Large foreign-owned banks have higher margins compared to smaller local-owned banks.

Hypothesis 4: The increase in bank competition affects the reduction of the net interest margin.

\section{Empirical analysis}

Many empirical studies have been conducted to identify the determinants of the net interest margin, as the group of countries, as well for particular economies; as for individual banks, as well for aggregated data at the system level. Banking systems of economies in the process of liberalization and reform of financial systems are not in long-term equilibrium (Brock and Rojas-Suarez, 2000). For this reason, the interpretation of the results obtained must be done with caution as they are not direct as it is for developed economies. In this regression analysis are presented a total ten variables, one of which is a dependent variable and eight others are independent variable. For details you can see below on specification of model and conceptual study plan.

\subsection{Specification of the model}

The equation to be assessed can be summarized as follows:

$$
\begin{aligned}
& \text { NIM it }=\alpha i+\beta 1 \cdot P P i t+\beta 2 \cdot \text { QRit }+\beta 3 \cdot \text { LQit }+\beta 4 \cdot \text { CRit }+\beta 5 \cdot \text { OEit }+\beta 6 \cdot \text { Sit }+\beta 7 \cdot \text { Oit }+ \\
& \beta 8 \cdot \mathrm{PBBit}+\beta 9 \cdot \mathrm{HHIit}+\beta 10 \cdot \mathrm{X} 1 \mathrm{t}+\beta 11 \cdot \mathrm{X} 2 \mathrm{t}+\beta 12 \cdot \mathrm{X} 3 \mathrm{t}+\beta 13 \cdot \mathrm{X} 4 \mathrm{t}+\beta 14 \cdot \mathrm{X} 5 \mathrm{t}+\varepsilon \mathrm{it}^{1}
\end{aligned}
$$

Where:

$\mathrm{i}=1.2 \ldots . ., \mathrm{N}$ is the bank; $\mathrm{t}=4.5 \ldots . ., \mathrm{T}$ belongs to the respective year of consideration; $\alpha$ i, $\beta 1, \beta 2, \beta 3, \beta 4, \beta 5, \beta 6, \beta 7, \beta 8, \beta 9, \beta 10, \beta 11, \beta 12, \beta 13, \beta 14$ is a vector of parameters and $\alpha i$ represents Fixed Effects, while $X$ is a vector of country

\footnotetext{
${ }^{1}$ Dealer model (Ho and Saunders, 1986)
} 
variables. Where, X1 is Albania, X2 is Bosnia and Herzegovina, X3 is Kosovo, X4 is Macedonia and X5 is Serbia. And $\varepsilon$ represents the model error term.

\subsection{Conceptual study plan}

The calculation of the variables is explained in the square to the conceptual plan of the study, which is the main reference point of this paper. Net interest margin (NIM) is the dependent variable, while the portfolio performance (PP), risk sustainability $(\mathrm{QR})$, liquidity risk (LQ), credit risk (CR), operating expenses (OE), bank size (S), capital ownership (O), Gross Domestic Products (GDP) and market structure (HHI) are the independent variables. The seven first variables include bank variables, while the GDP is macroeconomic variables and HHI is the market variables.

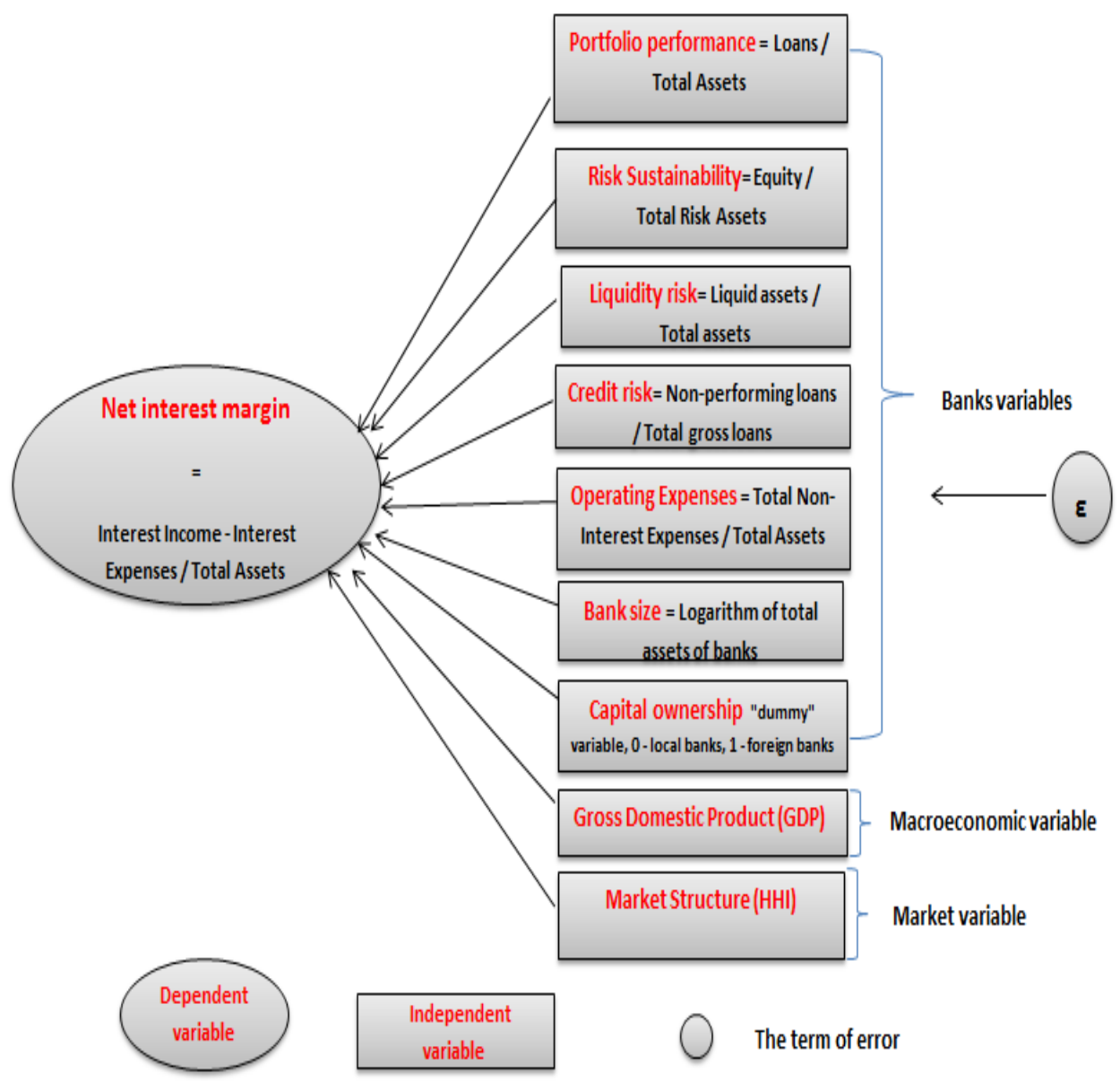

Figure1. Conceptual study plan 


\subsection{Empirical results}

The regression analysis is presented in two models: static and dynamic model. The static model includes four equations (Table no.1). In the first equation are the independent variables of banking character, such as: PP, QR, LQ, CR, OE, and S., in front of the dependent NIM variable. Then the second equation is added the independent variable of macroeconomic character GDP that indicate economic development. While in the third equation there is another independent variable that shows the market structure by HHI. And at the end of the static model is presented the fourth equation that representing the independent variable on the ownership of bank capital.

Table no. 1 Static model of empirical results

\begin{tabular}{|c|c|c|c|c|}
\hline Independent vaiable & $\begin{array}{c}\text { Ekuation } \\
1\end{array}$ & $\begin{array}{c}\text { Ekuation } \\
2\end{array}$ & $\begin{array}{c}\text { Ekuation } \\
3\end{array}$ & $\begin{array}{c}\text { Ekuation } \\
4\end{array}$ \\
\hline PP & $\begin{array}{l}0.211^{* * *} \\
(0.047)\end{array}$ & $\begin{array}{l}0.218^{* * *} \\
(0.049)\end{array}$ & $\begin{array}{l}0.219^{* * *} \\
(0.049)\end{array}$ & $\begin{array}{l}0.220^{* * *} \\
(0.049)\end{array}$ \\
\hline QR & $\begin{array}{l}0.597^{* * *} \\
(0.075)\end{array}$ & $\begin{array}{l}0.603^{* * *} \\
(0.075)\end{array}$ & $\begin{array}{l}0.603^{* * *} \\
(0.076)\end{array}$ & $\begin{array}{l}0.602^{* * *} \\
(0.075)\end{array}$ \\
\hline LQ & $\begin{array}{l}0.093^{* *} \\
(0.042)\end{array}$ & $\begin{array}{l}0.098^{* *} \\
(0.042)\end{array}$ & $\begin{array}{l}0.100^{* *} \\
(0.042)\end{array}$ & $\begin{array}{l}0.100^{* *} \\
(0.042)\end{array}$ \\
\hline CR & $\begin{array}{l}0.222^{* * *} \\
(0.049)\end{array}$ & $\begin{array}{l}0.213^{* * *} \\
(0.046)\end{array}$ & $\begin{array}{l}0.216^{* * *} \\
(0.048)\end{array}$ & $\begin{array}{l}0.211^{* * *} \\
(0.045)\end{array}$ \\
\hline $\mathrm{OE}$ & $\begin{array}{l}0.116^{* * *} \\
(0.011)\end{array}$ & $\begin{array}{l}0.119^{* * *} \\
(0.014)\end{array}$ & $\begin{array}{l}0.111^{* * *} \\
(0.015)\end{array}$ & $\begin{array}{l}0.110^{* * *} \\
(0.014)\end{array}$ \\
\hline$S$ & $\begin{array}{l}0.354^{* * *} \\
(0.055)\end{array}$ & $\begin{array}{l}0.350^{* * *} \\
(0.054)\end{array}$ & $\begin{array}{l}0.352^{* * *} \\
(0.055)\end{array}$ & $\begin{array}{l}0.349^{* * *} \\
(0.054)\end{array}$ \\
\hline GDP & & $\begin{array}{l}-0.000 \\
(0.000)\end{array}$ & $\begin{array}{l}-0.000 \\
(0.000)\end{array}$ & $\begin{array}{l}-0.000 \\
(0.000)\end{array}$ \\
\hline $\mathrm{HHI}$ & & & $\begin{array}{l}-0.000 \\
(0.000)\end{array}$ & $\begin{array}{l}-0.000 \\
(0.000)\end{array}$ \\
\hline 0 & & & & $\begin{array}{l}0.315^{* * *} \\
(0.032)\end{array}$ \\
\hline Const & $\begin{array}{l}0.754^{* * *} \\
(0.075)\end{array}$ & $\begin{array}{l}0.763^{* * *} \\
(0.075)\end{array}$ & $\begin{array}{l}0.771^{* * *} \\
(0.077)\end{array}$ & $\begin{array}{l}0.782^{* * *} \\
(0.063)\end{array}$ \\
\hline $\mathrm{R}^{2}$ & 0.715 & 0.715 & 0.711 & 0.707 \\
\hline Wald chi' ${ }^{2}$ & $155^{* * *}$ & $154^{* * *}$ & $150^{* * *}$ & $150^{* * *}$ \\
\hline
\end{tabular}

The second model is the dynamic model that includes all variables as the static model. Also, this model consists in four equations. It differs from the static model because here are presented the states and their comparison (Table no. 2). As a referencing country in the dynamic model, towards other countries is taken Albania. 
Table No. 2 Dynamic model of empirical results

\begin{tabular}{|c|c|c|c|c|}
\hline Independent variable & $\begin{array}{c}\text { Ekuation } \\
1 \\
\end{array}$ & $\begin{array}{c}\text { Ekuation } \\
2 \\
\end{array}$ & $\begin{array}{c}\text { Ekuation } \\
3 \\
\end{array}$ & $\begin{array}{c}\text { Ekuation } \\
4 \\
\end{array}$ \\
\hline \multirow[t]{2}{*}{ PP } & $0.221^{* * *}$ & $0.185^{* * *}$ & $0.187^{* * *}$ & $0.188^{* * *}$ \\
\hline & $(0.047)$ & $(0.049)$ & $(0.049)$ & $(0.050)$ \\
\hline \multirow[t]{2}{*}{ QR } & $0.597 * * *$ & $0.606^{* * *}$ & $0.605^{* * *}$ & $0.605^{* * *}$ \\
\hline & $(0.075)$ & $(0.080)$ & $(0.080)$ & $(0.080)$ \\
\hline \multirow[t]{2}{*}{ LQ } & $0.093^{* *}$ & $0.091^{* *}$ & $0.084^{* *}$ & $0.084^{* *}$ \\
\hline & $(0.042)$ & $(0.043)$ & $(0.042)$ & $(0.042)$ \\
\hline \multirow[t]{2}{*}{ CR } & $0.212^{* * *}$ & $0.217^{* * *}$ & $0.219^{* * *}$ & $0.221^{* * *}$ \\
\hline & $(0.042)$ & $(0.048)$ & $(0.044)$ & $(0.041)$ \\
\hline \multirow[t]{3}{*}{$\mathrm{OE}$} & $0.114^{* * *}$ & $0.117^{* * *}$ & $0.116^{* * *}$ & $0.117^{* * *}$ \\
\hline & $(0.020)$ & $(0.021)$ & $(0.021)$ & $(0.022)$ \\
\hline & $0.350^{* * *}$ & $0.343^{* * *}$ & $0.341^{* * *}$ & $0.339^{* * *}$ \\
\hline s & $(0.054)$ & $(0.050)$ & $(0.050)$ & $(0.049)$ \\
\hline \multirow[t]{2}{*}{ GDP } & & -0.000 & -0.000 & -0.000 \\
\hline & & $(0.000)$ & $(0.000)$ & $(0.000)$ \\
\hline \multirow[t]{2}{*}{ BOSNIA and HERZEGOVINA } & & $0.091^{* * *}$ & $0.089^{* * *}$ & $0.088^{* * *}$ \\
\hline & & $(0.029)$ & $(0.029)$ & $(0.029)$ \\
\hline \multirow[t]{2}{*}{ kosovo } & & $0.150^{* * *}$ & $0.157^{* * *}$ & $0.158^{* * *}$ \\
\hline & & $(0.040)$ & $(0.041)$ & $(0.042)$ \\
\hline \multirow[t]{2}{*}{ MAKEDONIA } & & $0.129^{* * *}$ & $0.132^{* * *}$ & $0.132^{* * *}$ \\
\hline & & $(0.033)$ & $(0.033)$ & $(0.033)$ \\
\hline \multirow[t]{2}{*}{ SERBIA } & & $0.164^{* *}$ & $0.162^{* *}$ & $0.161^{* *}$ \\
\hline & & $(0.065)$ & $(0.065)$ & $(0.065)$ \\
\hline \multirow[t]{2}{*}{$\mathrm{HHI}$} & & & -0.000 & -0.000 \\
\hline & & & $(0.000)$ & $(0.000)$ \\
\hline \multirow[t]{2}{*}{0} & & & & $0.414^{* * *}$ \\
\hline & & & & $(0.061)$ \\
\hline \multirow[t]{2}{*}{ Const } & $0.754^{* * *}$ & $0.736^{* * *}$ & $0.743^{* * *}$ & $0.753^{* * *}$ \\
\hline & $(0.075)$ & $(0.077)$ & $(0.060)$ & $(0.062)$ \\
\hline $\mathrm{R}^{2}$ & 0.715 & 0.737 & 0.738 & 0.735 \\
\hline Wald chi ${ }^{2}$ & $117^{* * *}$ & $116^{* * *}$ & $115^{* * *}$ & $115^{* * *}$ \\
\hline
\end{tabular}

From the regression analysis, the above tables show these econometric results: The most important factor with high influence on the NIM it comes from the risk sustainability variable $(\mathrm{QR})$ or the relation from equity to total risk assets. The value in the model is .597 and reaches to .605 , this is presented with the greatest value and identified as the most significant variable, which means that banks with a relatively higher level of capital adequacy are perceived as safer and this is liked by the public. This is the reason why banks are forced to lower their funding costs by lowering their deposit interests but also avoiding leakage of deposits during this process. Moreover, holding a high level of capital is a tool for banks to signal solvency and 
creditworthiness and inspire depositors' confidence, especially in the Balkan countries with an approximately constant value around .350 to .400 that influencing NIM is these factors, such as: Size $(\mathrm{S})$ and bank ownership $(\mathrm{O})$. Their value is a significant factor, which means that foreign-owned banks and large banks at the same time tend to increase the net interest margin as opposed to small and local-owned banks. Other factors that influencing NIM and there are significant also, such as: Portfolio performances (PP) or credit ratio with total assets, Credit risk (CR) or non-performing loans in relation to gross loans. The higher credit risk, the higher is the interest rates of loans. Also, operating costs (OE) have emerged as a significant factor in NIM. Significant but with less influential factors have been the liquidity risk (LQ). While non-impacting factors with zero value are estimated GDP and HHI. This means that the economy and competition are not relatively high factors in the impact of interest rates. Also, you can see at the dynamic model that all states have become significant. Testing the hypothesis is done through the $\mathrm{R}^{2}$ and Wald chi ${ }^{2}$ tests. From the results that presented in the table it is seen that $\mathrm{R}^{2}$ in all equations is over $70 \%$, which means that the model is representative The variance Inflation Factors (VIF), it results in a value of 5.16 that meaning that the variables are correlated. By equating all the parameters of $\beta$ with zero $(\beta=0)$, the Wald chi $^{2}$ test drops the zero hypothesis and gives a significant alternative hypothesis value. The values of the Wald chi ${ }^{2}$ test in the first model range from 150 to 155 ; while in the second model is 115-117.

\subsection{Finding analysis}

We can conclude that the hypotheses above have been tested by pointing out these findings:

Finding no.1: The level of capital adequacy (the ratio of regulatory capital to riskweighted assets) is the main growth factor of the net interest margin in countries such as Kosovo.

Finding no.2: Large and foreign-owned banks have better growth impact on the net interest rate spread in the Balkan countries than smaller and local-owned banks.

Finding no.3: Portfolio performance, operating expenses, credit risk and liquidity risk are other factors influencing the increase in the net interest margin.

Finding no.4: The generally average level of competition does not seem to have affected the net interest margin.

\section{Conclusion}

In theory is known that the determinate of proper level of capital by banks is a very important task in risk management. A high level of capital protects the bank from bankruptcy in the event of huge and unexpected losses. But on the other hand, for other things that are unchanged, a higher level of capital than is required burdens the bank's profit. In the second case we are dealing with costs that come from higher security than it is required, and in places like Kosovo, a part of the "cost of security" that comes from the highest level of capital to the minimum than is required, banks transmit to businesses clients and private clients who take loans and open Term deposits. Finally, based on regression estimates, the main "responsible" of the net interest margin in Kosovo and other countries that have been researched in this paper 
are in the descending order: the level of capital adequacy (or risk sustainability), size and ownership of foreigner banks, portfolio of performance, credit risk, operating expenses and liquidity risk. This result supports our main hypothesis. Intuitively, this result can be explained as follows: Banks with a relatively higher level of capital adequacy are perceived as safer and this is liked by the public. This is the reason why banks are forced to lower their funding costs by lowering their deposit interests but also avoiding leakage of deposits during this process. The results obtained from this study may serve policymakers to focus on issues that are more related to the determinants of the net interest margin. Greater attention may be paid to maintaining the level of capital through the mandatory reserve rate, the ownership structure and size, the level of non-performing loans, the level of operating expenses and the degree of competition. Such an approach may be useful for specific measures of economic policy, taking into account the prospect of EU integration and other researchers wishing to expand this study. This work can be continued in the future by expanding in different directions for example, including longer periods of study, with the extension of the data series, it is possible to include other variables, especially the nature of macroeconomic, regulatory and legal issues.

\section{References}

1. Abreu, M. M. (2003). Do Macro-Financial variables matter for European bank interest margins and profitability? Financial Management Association International.

2. Afanasieff, T. S. (2002). . "The Determinants of Bank Interest Rate Spreads in Brazil". Central Bank of Brazil Working Papers, 46 .

3. Agoraki, M. E. (2010). The determinants of net interest margin during transition, Grecee, Athens University of Economics and Business. Greece, Athens University of Economics and Business.

4. Albulescu. (2009). Forecasting credit growth rate in Romania: from credit boom to credit crunch? MPRA Paper 16740.

5. Angbazo, L. (1997). Commercial bank net interest margins, default risk, interest rate risk and off-balance sheet banking. . Journal of Banking and Finance 21, 55-87.

6. Ansgar Belke, T. P. (2009). Monetary Economics in Globalized Financial Markets. Berlin Heidelberg: Springer-Verlag.

7. Athanasoglou, P., Delis, M., Staikouras, C., 2006. Determinants of Bank Profitability in the South Eastern European Region. Journal of Financial Decision Making 2(2), 1-17.

8. Berger, A. B. (2000). Why are bank profits so persistent? The roles of product market competition, informational opacity, and regional/macroeconomic shocks. . Journal of Banking and Finance 24, 1203 1235 . 
9. Berger, A.N., Buch, C.M., DeLong, G., De Young, R., (2004). Exporting Financial Institutions Management via Foreign Direct Investment Mergers and Acquisitions. Journal of International Money and Finance 23, 333-366.

10. Berger, A. M. (1997). Inside the black box: What explains differences in the efficiencies of financial institutions? Journal of Banking and Finance 21, 895-947.

11. Berger, A. (1995). The relationship between capital and earnings in banking. Journal of Money, Credit and Banking. Vol.27.

12. Bernanke, B. (1983). "Nonmonetary effects of the financial crisis in the propagation of the Great Depression". American Economic Review, 73,25 776.

13. Bomfin, A. N. (2001). Measuring equilibrium real interest rates: what can we learn from yields on indexed bonds? Federal Reserve Board, Finance and Economics Discussion Series.

14. Brock, P., Suarez, L.R., 2000. Understanding the Behavior of Bank Spreads in Latin America. Journal of Development Economics 63, 113-134.

15. Brock, P. a. (2000). Interest rate spreads in Latin America: Facts, Theories and Policy Recommendations. Inter-American Development Bank, 7,25-28.

16. Brock, P. a. (2002). Bank Interest margins Meet Interest Rate Spreads: How Good is Balance Sheet Mimeo Central Bank of Chile. Data for Analyzing the Cost of Financial Intermediation? Mimeo Central Bank of Chile.

17. Carbo V.S., R. F. (2007). The determinants of bank margins in European banking. . Journal of Banking and Finance, 31, 2043-2063.

18. Claeys, S. V. (2007). Determinants of Bank Interest Margins in Central and Eastern Europe: A Comparison with the West. Economic Systems 32, 197 216.

19. Claeys, Sophie and Rudi Vander Vennet, (2004). Determinants of Bank Interest Margins in Central and Eastern Europe: A Comparison with the West". Ghent University Working Papers, 316

20. Corvoisier, S. and R. Gropp. (2002). "Bank concentration and retail interest rates". Journal of Banking and Finance 26

21. Demirgüç-Kunt, A. a. (1998). "Determinants of Commercial Bank Interest Margins and Profitability: Some International Evidence". The World Bank Policy Research Working Paper, 1900, 379-408.

22. Demirguç-Kunt, H. (1999). The determinants of Commercial Bank Interest Margins and Profitability: Some International Evidence. The World Bank Economic Review, Vol.13, 379-408.

23. Demsetz, H. (1973). Industrial structure, market rivalry, and public policy. Journal of Law and Economics, 16, 1-10.

24. Drakos. (2002). The Dealership model for interest margins: The case of the Greek banking industry. Journal of Emerging Finance 1, 75-98.

25. Drakos, K. (2003). Assessing the success of reform in transition banking 10 years later: an interest margins analysis. Journal of Policy Modeling 25, 309317.

26. Fisher, I. (1907). The rate of interest. New York: Macmillan: reprinted in Fisher 1997. 
27. Friedman, M. (1994). Money mischief, episodes in monetary history. . San Diego: Hartcourt Brace, 50-52.

28. Garrison, R. W. (2002). Ditch the Keynesians, why policy-infected interest rates mustgo. . Barron's, 82 (35), 2.

29. Gossen, H. H. (1854.). Entwicklung der Gesetze des menschlichen Verkehrs und der daraus fließenden Regeln f'ur menschliches Handeln. Braunschweig, Viehweg.

30. Keynes, J. M. (1973). The general theory of employment, interest, and money. . USA: Cambridge. 156

31. Knut, W. (1969). The influence of the rate of interest on commodity prices. UK: Reprinted Knut.

32. Levine, R. (2004). Financial Development and Economic Growth”. Journal of Economic Literature, 35 (2).

33. Martinez Peria, M. M. (2004). How Foreign Participation and Market Concentration Impact Bank Spreads: Evidence from Latin America. . Journal of Money, Credit, and Banking 36, 511-537.

34. Martinez Peria, M. S. (1998). Do Depositors Punish Banks for Bad Behavior? Discipline in Argentina, Chile, and Mexico. World Bank Policy Research Working Paper No. 2058.

35. Maudos, J. a. (2004). "Factors explaining the interest margin in the banking sectors of the European Union". Journal of Banking and Finance 28, 225, 9$22,81$.

36. McShane, R. a. (1985). "A time series/cross section analysis of the determinants of Australian trading bank loan/deposit interest margins: 1962 1981". . Journal of Banking and Finance 9, 115-136.

37. Mises, L. (1996). Human action. San Francisco: Fox \& Wilkes., 527.

38. Naceur, B. S. (2003). The determinants of the Tunisian Banking Industry profitability: Panel evidence. University of Libre de Tunis, Department of Finance Working Paper.

39. Nelson, N. \&. (2003). The real interest rate gap as an inflation indicator. Macroeconomic Dynamics, 7(2), 239-262.

40. Nys. (2003). A European study of bank interest margins: is net fees revenue a determinant? 20th Symposium, Birmingham Research into International Economics and Finance.

41. Reifschneider, D. \&. (2000). Three lessons for monetary policy in a lowinflation area. Journal of Money, Credit and Banking, 936-966.

42. Rothbard (2001). Man, economy, and state, power and market, a treatise on economic. Auburn: AL: Ludwig von Misses Institute.

43. Sapienza, P., (2002). What Do State-Owned Firms Maximize? Evidence from the Italian Banks. CEPR Discussion Paper No. 3168.

44. Schumacher, S. a. (2000). "The determinants of bank interest rate margins: an international study". Journal of International Money and Finance, 19.

45. Sologoub, D. (2006). The Determinants of Bank Interest Margins and Profitability, Case of Ukraine. Workshop on transition economics, Helsinki, April.

46. Wicksell, K. (1898, 1965). Interest and Prices. Translated by R. F. Kahn, London, Macmillan; 
47. Wicksell, K. (1969). The influence of the rate of interest on commodity prices. Reprinted in Knut. Selected papers on Economic Theory, New York, 67-89.

48. Woodford, M. (2000). A Neo-Wicksellian framework for analyzing monetary policy. Working.

49. Woodford, M. (2003). Interest and prices. Princeton, New York, Princeton University Press. 